\title{
PEMBELAJARAN ILMU PENGETAHUAN SOSIAL SEBAGAI SARANA PEMBENTUKAN KARAKTER SISWA MENGHADAPI REVOLUSI INDUSTRY 4.0
}

\section{Gallih Arya Mulyadi dan Firman dan Rusdinal}

Universitas Negeri Padang, Sumatera Barat, Indonesia

Email: gallih.a.mulyadi@gmail.com, firman@konselor.org

dan rudinal@fip.unp.ac.ud

\section{Abstract}

This article aims to provide an awareness of the need for character learning as well as strengthening the character of students in an effort to face the industrial revolution 4.0. Oneway, namely with the study of social sciences. No less important is also the synergy between parents, schools, teachers and the social environment in order to make the nation's successor students become able to face and compete in industry 4.0. The method used to analyze this problem is to use descriptive qualitative methods, namely with the study of literature,Kajian literature used in this article is to use various references to books, journal articles, proceeding seminars, and various other academic manuscripts. Once collected, then conducted analysis of the study according to the topic in the article. In the era of industrial revolution 4.0 today everything is always accessed and facilitated with internet access. This revolution also made changes and habits and patterns that exist in society. This new habit is a dependency with mobile devices and gadgets. The result is the existence of social perubhan in the community that makes the socialization of the community is not as solid and as famous as before. This is the latent effect of the revolution and the developments that took place. The results of this article reveal that the need for character defects, especially in the character of students to be able and adaptive in existing social development, then ips learning can be one way and soslusi in efforts to shape the character of students to face the industrial revolution 4.0.

Keywords: socialsciences; character formation; industry 4.0

\begin{abstract}
Abstrak
Artikel ini bertujuan untuk memberikan pengetahun akan perlunya pembelajaran karakter serta penguatan karakter siswa dalam upaya menghadapi revolusi industri 4.0. Salah satu caranya yakni dengan pembelajaran ilmu pengetahuan sosial. Tak kalah penting juga adalah sinergi antara orang tua, sekolah, guru dan lingkungan sosial agar menjadikan siswa penerus bangsa ini menjadi mampu menghadapi serta bersaing di zaman industri 4.0. Metode yang digunakan untuk menganalisa masalah ini adalah dengan menggunakan metode kualitatif deskriptif yakni dengan kajian literatur, kajian literatur yang digunakan dalam artikel ini adalah menggunakan berbagai referensi buku, artikel jurnal, prosiding seminar, dan berbagai naskah akademik lainnya. Setelah dikumpulkan, kemudian dilakukkan analisa kajian sesuai topik pada artikel. Pada era revolusi industri 4.0 saat ini segalanya selalu diakses
\end{abstract}


dan dimudahkan dengan akses internet. Revolusi ini juga membuat perubahan dan kebiasaan serta pola yang ada di masyarakat. Kebiasan baru ini adalah sebuah ketergantungan dengan perangkat mobile dan gawai. Akibatnya adalah adanya perubahan sosial dalam masyarakat yang membuat sosialisasi masyarakat menjadi tidak sesolid dan seterus yang terdahulu. Hal ini adalah efek laten dari revolusi dan perkembangan yang terjadi. Hasil dari artikel ini mengungkapkan bahwa perlunya pembetukan karakter terutama pada karakter siswa untuk mampu dan bisa adaptif dalam perkembangan sosial yang ada, kemudian pembelajaran IPS bisa menjadi salah satu cara dan soslusi dalam upaya pembentukan karakter siswa untuk menghadapi revolusi industri 4.0.

Kata kunci: ilmu pengetahuan sosial; pembentukan karakter; industri 4.0

\section{Coresponden Author}

Email: gallih.a.mulyadi@gmail.com Artikel dengan akses terbuka dibawah lisensi

\section{Pendahuluan}

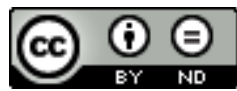

Pembentukan karakter siswa pada dasarnya adalah tugas bersama dimulai dari sosialisasi primer dirumah yakni orangtua siswa sebagai agennya, lalu kemudian sekolah dan guru sebagai agensi sekunder dalam pembentukan karakter siswa. Untuk itu perlulah kolaborasi yang baik antara orangtua siswa dan para guru (Irwan, 2017).

Orang tua mempunyai andil yang besar sebgai agen sosialisasi primer untuk membentuk karakter dan kepribadian anaknya. Sebagai Orang tua semestinya sedini mungkin menanamkan nilai dan norma yang ada kepada anaknya sebagai bekal dan dasar karakter anak terbentuk. Bila orang tua menanamkan serta mengajarkan sesuatu hal yang baik, mengajarkan tentang norma-norma kesopanan yang baik juga, tentu akan terciptalah seorang individu anak yang memiliki karakter yang baik serta santun. Apabila di rumah anak sudah diajarkan dengan sifat-sifat baik yang sesuai dengan norma dan peraturan, tentunya saat diluar rumah karakter yang terbentuk adalah sudah menjadi anak yang baik dan mempunyai kepribadian dan karakter yang baik pula. Saat si anak melangkah dan berada di sekolah yakni tempat sosialisasi sekundernya tentunya guru sebgai agen sosialisasi sekundernya tidak susah payah lagi untuk mengajarkan dan membentuk karakter siswa didiknya dan kemudian para guru semakin fokus untuk memberikan belajar dan pengajaran ilmunya. Kenyataannya saat ini adalah orang tua seakan-akan lepas tanggung jawab dan menyerahkan sepenuhnya ke sekolah dan guru tentang pembentukan karakter siswa sehingga, sering terjadinya salah komunikasi antara orang tua dan guru.

Kenyataannya saat ini banyak aspek dan tantangan dalam pembentukan karakter siswa ini. Tantangan yang paling nyata adalah soal keterbukaan akses yang saat ini semakin bebas. Keterbukaan akses ini maksudnya adalah sebuah era atau masa yang segala sesuatunya mudah didapat dan berbentuk digital serta komputerisasi. Tentunya hal ini bukan hanya berdampak baik dan positif bagi kita tapi juga mempunyai dampak 
yang buruk bila kita salah menggunakannnya. Akses yang mudah ini di tandai lalu dinamakan dengan revolusi industri 4.0.

Revolusi industri 4.0 adalah kata-kata yang paling sering kita dengarakan. Dibalik kemudahan, keterbukaan serta kebebasan untuk berpendapat yang ditawarkan pada era ini akibat kemajuan teknologi, tentunya menyimpan sisi negatif yang juga terdapat disana. Pertanyaannnya adalah apakah kita dan anak-anak kita sudah siap untuk menghadapai era industri 4.0. Jawabannya bisa siap dan bisa tidak siap, mengapa demikian, karena kesiapan kita dalam menghadapi industri 4.0 ini bisa kita lihat dari kesiapan kita mendidik mental dan karakter anak kita. Untuk itulah pendidikan IPS memiliki peranan yang sangat penting akan hal itu (Setiawan et al., 2020).

Pendidikan IPS juga memberikan pembelajaran tentang pendidikan karakter serta pendidikan nilai yang mempunyai untuk menyiapkan peserta didik menjadi warga negara yang baik. yang peduli akan lingkungan sosialnya. Oleh karena itu, diperlukan pengembangan kurikulum pendidikan di sekolah yang menggabungkan aspek pengetahuan, sikap, nilai, moral dan keterampilan, Untuk itulah materi pembelajaran IPS dirancang serta disusun untuk memperkenalkan konsep yang berkaitan di lingkungan sosial. Untuk itu guru IPS harus berpegang dengan 5 prinsip pembelajaran, yakni pembelajaran yang bermakna, pembelajaran yang terpadu, pembelajaran yang mempunyai tantangan, pembelajaran yang aktif, dan pembelajaran yang berbasis nilai. Sehingga pembelajar IPS dapat menciptakan suasana pembelajaran yang kondusif dan produktif, sehingga memberikan pengalaman pembelajaran yang baik dan akhirnya akan menimbulkan efek yang positif dan sesuai dengan tujuan dari pembelajaran pembentukan karakter melalui pendidikan IPS (Marhayani, 2018).

Akses keterbukaan yang sangat bebas ini jangan sampai membuat anak-anak kita hilang karakternya dan meniru lalu memakai kebiasaan dan budaya bukan Indonesia dan menghilangkan karakter dan lalu merubah karakter diri tidak lagi seperti karakter bangsa Indonesia. Untuk itu perlu usaha lebih keras lagi orangtua dalam upaya pembentukan karakter anak agar bisa adaptif serta terampil menghadapi revolusi industri 4.0. Pembentukan karakter dalam hal ini adalah membentuk karakter anak yang mampu bersaing serta adaptif akan perkembangan jaman serta tantangan dari fase industri 4.0. Untuk itulah sangat diperlukannya pembelajaran IPS sebagai salah satu upaya menciptakan karakter siswa yang mampu menghadapi revolusi industri 4.0.

\section{Metode Penelitian}

Metode yang digunakan dalam artikel ini yaitu deskriptif kualitatif yakni dengan mengumpulkan kajian literatur terkait dengan pembelajaran IPS sebagai sarana menciptakan karakter siswa dalam menghadapi tantangan revolusi industri 4.0. Kajian literatur yang digunakan dalam artikel ini adalah menggunakan berbagai referensi buku, artikel jurnal, prosiding seminar, dan berbagai naskah akademik lainnya. Setelah dikumpulkan, kemudian dilakukkan analisa kajian sesuai topik pada artikel. 


\section{Hasil dan Pembahasan}

Perkembangan jaman semakin tidak bisa kita bendung lajunya. Hal ini juga sejalan dengan perkembangan manusia serta pola pikirnya. Perkembangan jaman dan teknologi yang pesat, tanpa disadari kita telah berada pada era atau fase industri 4.0. Era industri 4.0 ini sedang sangat hangat diperbincangkan oleh orang banyak. Sebenarnya apa itu era industri 4.0 ini, mengapa topik ini menjadi hangat dan sering diperbincangkan, lalu mengapa kita langsung berada di fase 4.0, kemana fase 1.0,2.0,3.0 ? pertanyaan selanjutnya adalah apakah kita siap menghadapi revolusi industri 4.0 ini. Untuk itu penulis dalam artikel ini berpaya untuk mendiskripsikan serta menjelaskan semua pertanyaan yang ada tadi. Seperti yang sudah diungkapkan oleh (Schwab, 2017), dalam bukunya "The Fourth Industrial Revolution" diawali dengan tahun 1760 adanya perubahan yang sangat cepat dibidang industri yakni adanya penemuan rel kereta api dan penemuan mesin uap, setelahnya akhir abad 19 adanya penemuan listrik yang menandai revolusi industri kedua. Seterusnya pada tahun 1960 penemuan komputer menjadi penanda revolusi ketiga, lalu kemudian pada abad 21 disebut sebagai Revolusi Industri 4.0 yang ditandai dengan mobile dan internet. Kemunculan penemuan internet ini menjadi pengubah segalanya. Internet mengubah dari segala sendi kehidupan dan keberadaannya terus memberikan perubahan diberbagai bidang kehidupan. Mulai dari kehidupan perekonomian, teknologi, dunia perpolitikan, sosial budaya dan juga dalam bidang pendidikan. Contoh yang kita tahu saat ini berkembangnya e-commerce, pengembangan aplikasi berbelanja yang bisa di akses langsung melalui smartphone sehingga orang-orang sudah tidak lagi berbelanja langsung ke toko fisik dan itu mengakibatkan perubahan budaya berbelanja masyarakat yang semakin konsumtif karena kemudahan untuk berbelanja dan mengaksesnya. Kemudian internet juga menembus semua batasan-batasan dan halangan yang ada dengan dimudahkan melalui internet dan komputerisasi. Batasan seperti ruang, jarak dan waktu pun sudah tidak ada lagi batasannya semua dipermudah dengan internet dan didukung dengan perangkatperangkat mobile yang makin praktis dan kompak.

Revolusi industri 4.0 yang di tandai oleh kompeterisasi dan internet ini juga membentuk sebuah kebiasaan baru. Kebiasaan baru ini adalah sebuah ketergantungan dengan perangkat mobile dan smartphone. Masyarakat saat ini semakin dimanjakan dengan teknologi dan pengembangannya. Namun ada sisi lain yang harus juga kita soroti saat ini, adalah efek dari itu semua. Efek ketergantungan akibat dari kemudahan dan kenyamanan menggunakan teknologi internet dan smartphone yang malah meng disrupsi atau mengurangi nilai humanis dari manusia. Meskipun dimudahkan dengan kenyamanan akses dan ikemudahan mendapatkan segala informasi namun Manusia era ini adalah manusia yang soliter dan tak acuh terhadap sekitar. Mereka lebih nyaman dan mudah berinteraksi melalui media sosial yang ada di internet dan bukan berkomunikasi secara langsung. Manusia semakin soliter dan makin semakin terbentuk menjadi masyarakat yang organis dan tidak lagi menjadi masyarakat yang mekanis seperti dulu.

Arus informasi yang begitu cepat juga menjadi ciri fase era ini. Namun sangat disayangkan meskipun segala informasi serba cepat dan aksesnya mudah untuk didapat 
namun masih banyak masyrakat yang belum siap akan hal ini, terbukti mudahnya masyarakat terhasut dan mudah dibohongi oleh berita atau informasi bohong atau yang sering kita sebut dengan istilah berita hoax. Selain dengan penyebaran dan percaya dengan berita-berita hoax tersebut, saat ini juga sering terjadi konflik dan pertengkaran serta ujaran kembencian di media sosial akibat ketidak mampuannya nmasyarakat untuk menahan diri serta argument untuk tidak saling menghina di kolom media sosialnya. Dari sini terlihat jelas bahwasannya memang masyarakat kita belum siap untuk hal semacam ini, untuk itu perlulah pengetahuan serata pola pikir yang baik lalu membentuk kepribadian yang mampu adaptif serta kritis terhadap perkembangan dan perubahan yang dibawa oleh fase industri ini.

Indonesia sebenarnya juga sudah bersiap dan menyambut fase dari industri 4.0. Negara dan masyrakat Indonesia saat ini telah dan sudah mempersiapkan diri untuk menghadapi perubahan serta perkembangan zaman yang serba digital, seperti yang sudah diuangkapkan Menteri Riset, Teknologi, dan Pendidikan Tinggi (Suwardana, 2018) menjelaskan, "Indonesia sudah berisiap dan akan menjadi negara yang mempunyai potensi tinggi guna menghadapi revolusi industri 4.0”. Segala macam cara yang digunakan bangsa Indonesia untuk siap menghadapi era revolusi industri 4.0, walaupun demikian dalam prakteknya selalu ada persoalan yang harus dihadapi, terutama permasalahan-permasalahan di dunia pendidikan.

Revolusi industri 4.0 juga ikut merubah pola dan kebiasaan yang ada di dunia pendidikan. Pendidikan di era industri 4.0 ini adalah proses perubahan pola belajar yang konvensional menjadi pola belajar yang berbasis internet atau yang sering kita dengar pola belajar e-learning. Siswa bisa belajar mandiri dengan menggunakan aplikasiaplikasi yang membantu para siswa untuk belajar. Selain itu juga pemberian tugas juga sudah mulai beralih dengan sistem yang sama. Namun tampa disadari dengan pola yang baru saat ini akan sebenarnya akan menimbulkan masalah. Masalah pertama adalah tentunya akses yang tidak merata dari sekolah satu dengan sekolah yang lain. Kedua kemungkinan adanya gagap teknologi yang dialami siswa dan tentunya para guru yang rata-rata sudah enggan untuk memakai dan belajar teknologi yang baru.

Permasalahan ini harus dikaji secara menyeluruh, karena yang menjadi dasar dalam kemajuan pendidikan adalah bukan sekedar keunggulan sarana dan teknologi, namun yang paling penting adalah keunggulan dari sumber daya manusianya yakni para guru dan pengajar yang berkualitas. Sebuah keharusan para pendidik bisa mentransmisikan dan memberi pelajaran ke peserta didik agar menjadi manusia yang seutuhnya. Hal ini sejalan dengan tujuan pendidikan Indonesia yakni pada UndangUndang RI No.20 Tahun 2003 perihal Sistem Pendidikan Nasional yaitu "pendidikan nasional mempunyai fungsi sebagai sarana untuk mencerdaskan kehidupan bangsa dan mempunyai tujuan sebagai sarana mengembangkan potensi peserta didik agar menjadi manusia beriman dan bertakwa kepada Tuhan Yang Maha Esa, berakhlak mulia, berilmu, sehat, cakap, kreatif, mandiri, dan menjadi warga negara yang demokratis dan bertanggung jawab" (Indonesia, 2003). 
Seperti yang termaktub dalam undang-undang tersebut fungsi dan tujuan pendidikan bukan hanya membentuk peserta didik yang pintar dan mempunyai kompetensi, kemampuan sesuai dengan perkembangan zaman. Sehingga menjadikan generasi muda yang berkualitas. Hasil penelitian dari (Akerib et al., 2016) adanya dampak dari digital tecnology menuju revolusi industri 4.0 dalam lima (5) tahun didepan muncul 52,6 juta jenis pekerjaan akan mengalami pergeseran dan kemudian hilang dari muka bumi. Hasil penelitian ini menunjukan bahwa setiap orang yang masih ingin mengikuti persaingan global yang harus mempersiapkan seseorang yang memiliki keunggulan psikologi dan teknis dibandingkan orang lain. Cara utama mempersiapkan keterampilan yang paling mudah untuk dikuasi adalah dengan mempertahankan prilaku yang baik (behavioral attitude) dan meningkatkan daya saing serta kualitas diri. Melalui pengalaman kolaborasi antargenerasi atau intradisipliner dan pendidikan jangka Panjang serta pengenalan konsep diri. Ternyata dalam hal ini mahasiswa yakni generasi muda harus memiliki soft skill agar dapat terus beradaptasi dengan perkembangan zaman. Kalaupun harus terbawa arus dan tergerus oleh era dan tren globalisasi yang dibawa Industri 4.0 tetapi masih mempunyai kepribadian yang sesuai dengan budaya Indonesia.

Oleh karenanya sangat penting bagi siswa untuk belajar ilmu pengetahuan sosial. Mengapa demikian, karena pelaksanaan dari IPS yang sangat signifikan itu adalah menciptakan generasi muda sebagai warga negara yang baik, mempunyai sifat sosial yang tinggi akan sesamannya, melestarikan dan mengamalkan kebudayaan Indonesia dan mempunyai sifat tanggung jawab yang tinggi. Ilmu Pengetahuan Sosial (IPS) adalah sebuah penggabungan dan pengintegralan beberapa pembelajaran di dalamnya, sehingga perlu penyampaian dalam proses belajar mengajar yang menarik serta penuh makna kemudian memadukan seluruh komponen pembelajaran agar efektif. Pembelajaran Ilmu Pengetahuan Sosial di sekolah adalah penggabungan serta penyerdehanaan ilmu sosial psikologi, filsafat, ideologi negara dan agama yang diorganisasikan kemudian diberikan secara ilmiah dan psikologis untuk tujuan pendidikan (Sumatri, 2014) Pembelajaran IPS memiliki peran yang sangat vital dalam upaya membina warganegara dalam proses membangun karakter bangsa. Karakter adalah seperangkat serta sekumpulan nilai-nilai yang telah menjadi kebiasaan hidup kemudian menjadi sifat yang tetap dalam diri seorang individu (Adisusilo, 2012). (Barr, Barth, \& Shermis, 1977) mengacu pada kajian Social Studies, dijelaskan bahwa:

"Social studies are the integrated study of the social sciences and humanities to promote civic competence. Within the school program, social studies provides coordinated, systematic study drawing upon such disciplines as anthropology, archaeology, economics, geography, history, law, philosophy, political science, psychology, religion, and sociology, as well as appropriate content from the humanities, mathematics, and the natural sciences. The primary purpose of social studies is to help young people develop the ability to make informed and reasoned decisions for the public good as citizens of a culturally diverse, democratic society in an interdependent world ".

IPS adalah integrasi dari berbagai disiplin ilmu sosial di dalamnya, bukan hanya ilmu sosial melainkan juga dari humanitis, ilmu matematika dan ilmu alam. Tujuan 
utama dari IPS adalah untuk membantu kaum muda yang mampu untuk mengambil keputusan agar bisa menjadi warga negara yang baik.

Konsep-konsep pembelajaran ilmu pengetahuan sosial juga harus ikut sesuai dengan perkembangan zaman. Menurut tujuan pembelajaran Ilmu Pengetahuan Sosial, adalah membentuk dan mengembangakan seseorang menjadi warga negara yang baik. Secara umum identitas warga negara yang baik menurut Robert Barr seperti yang ditulis oleh (Ilbert et al., 2013), dapat digambarkan sebagai berikut: 1.) Mempunyai sikap patriotik (mencintai tanah air, bangsa dan negara), 2.) Menghormati dan memahami nilai, sistem, dan praktik kehidupan sosial, 3.) Memiliki integritas sosial dan tanggung jawab sebagai warga negara, 4.) Memahami dan menghormati nilai budaya atau tradisi yang diwarisi oleh negara, 5.) Memiliki motivasi untuk berpratisipasi aktif dalam penyelengaraan kehidupan demokrasi, 6.) Sadar akan masalah yang terjadi di lingkungan sosial, 7.) Mempunyai sikap, ide dan keterampilan sebagai warga negara, 8.) Memiliki pemahaman dan penghormatan terhadap sistem ekonomi saat ini.

Dalam kaitan ini (Winataputra, 2010) menguraikan adanya tiga tradisi pedagogis dalam kajian IPS, yakni:

1. Tradisi, Social Studies Taught as Citizenship Transmission tradisi ini bertujuan untuk mengembangkan warga negara yang baik, sesuai dengan nilai dan norma yang ada di suatu masyarakat, bangsa atau negara.

2. Tradisi, Social Studies Taught as Social Science tradisi ini terkait dengan pembentukan warganegara yang baik, yang ditandai dengan kemampuan dalam melihat dan mengatasi masalah-masalah sosial dan personal dengan menggunakan cara kerja ilmuwan sosial.

3. Tradisi, Social Studies Taught as Reflective Inquiry tradisi yang ditandai dengan pembentukan warga negara yang baik dengan ciri utamanya kemampuan mengambil keputusan dalam upaya mencari nilai tambah dan memecahkan masalah-masalah sosial.

Kemudian fokus tujuan pengajaran Ilmu Pengetahuan Sosial di sekolah memfokuskan pada empat komponen seperti yang dipaparkan oleh Chapin dan Messick yang ditulis oleh (Ilbert et al., 2013). 1. Memberi siswa pengetahuan tentang pengalaman manusia dalam kehidupan sosial di masa lalu, sekarang dan masa depan, 2. Membantu siswa mengembangkan keterampilan dalam mencari dan mengelola informasi, 3. Membantu siswa mengembangkan nilai atau sikap demokratis dalam kehidupan sosial, 4. Memeberikan siswa kesempatan untuk berpartisispasi dalam kehidupan sosial. Kemudian tujuan pembelajaran Ilmu Pengetahuan Sosial dalam aspek keterampilan menurut Fraenkel, J.R yang ditulis ulang (Ilbert et al., 2013) adalah 1. Keterampilan berfikir: dimulai dari pengamatan, menjelaskan kemudian membandingkan serta mempertentangkan, pengembangan konsep, menarik hipotesa dan lalu kemudian mengemukakkan pendapat. 2. Keterampilan akademis; membaca, melakukkan observasi, merumuskan masalah dan keterampilan menulis lainnya. 3. Keterampilan sosial; mampu berkordinasi dan bekerja secara tim. Pembelajaran IPS juga dapat melatih dan membisakan peserta didik untuk menghargai serta bangga akan 
warisan budaya dan peninggalan bangsa. Mengaplikasikan serta mengembangkan nilainilai budi pekerti luhur, mencontohkan nilai-nilai kepemimpinan, yang tak kalah penting juga adalah melatih keterampilan mengambil keputusan. (Sardiman, 2006) Oleh karena itu pembelajar IPS tidak hanya fokus kemampuan intelektual saja, namun juga dengan kecerdasan, akhlak, dan dan kpribadian yang digunakan dalam sosialisasi di masyarakat. Pembelajaran IPS memiliki peran strategis dalam membentuk karakter. Pendidikan karakter yang dapat dimaknai sebagai pendidikan nilai, pendidikan moral atau pendidikan budi pekerti (Darmiyati, 2008). Untuk itulah mengapa pembelajar IPS sangat perlu untuk membentuk karakter dalam mengahadapi revolusi industri.

Dengan pembelajaran IPS tentunya membuka lagi serta menggali lagi kemampuan dan daya yang ada di dalamdiri para siswa. Selain itu perlu juga adaptasi dan penyesuaian para guru IPS untuk memperbarui cara dan sistem belajar dalam proses pembelajaran. Guru harus terus up to date untuk bisa mengerti perkembangan dan bisa memasukkan pembelajajaran dengan gaya atau pola kekinian. Agar nantinya siswa tidak jenuh dan mampu menangkap semua pembelajaran (Nursyifa, 2019).

Meskipun saat ini sudah mulai dengan yang di sebutkan tadi yaitu pola belajar atau sistem belajar virtual atau e-learning. Saat ini banyak diminati peserta didik seperti aplikasi Quiper, Ruang Guru, Youtube dan Google yang begtu sangat mudah diakses saat ini, dengan perkembangan yang diatas menjadikan sebuah pandangan baru bahwasannya peran dan fungsi seorang guru akan tergantikan, oleh sebab itu kemampuan serta kompetensi guru harus segera di upgrade agar bisa beradaptasi dengan perkembangan zaman, tapi ada sisi dimana peran guru yang tidak bisa tergantikan adalah sisi pengajaran yang begitu nyata dan langsung berhadapan dengan murid akan tetap menjadi segi yang tak tergantikan oleh perkembangan jaman serta teknologi secanggih, terutama dalam hal pengajaran akan nilai dari setiap pembelajaran oleh karena itu para guru harus bisa menyemangati siswanya untuk terus menyunjung tinggi nilai dan norma yang ada di masyarakat, adanya komunikasi dua arah tersebut yang tak bisa tergantikan. Oleh karena itu perlu adanya peningkatan kemampuan serta keahlian guru untuk terus bisa beradaptasi dengan perkembangan jaman.

Guru IPS pada era ini juga haruslah wajib cakap akan kemampuan teknologi karena untuk menghadapi siswa-siswanya yang sudah mulai terbiasa dengan teknologi, mengingat peran guru sebagai fasilitator di kelas tentunya akan menjadi hambatan kalau guru tidak cakap teknologi. Para guru juga harus terus meng update pengetahuan dan informasi seputar mengembangkan kemampuan belajar, lalu kemuadian tidak lupa juga serta meng update keilmuannya mungkin dengan cara melanjutkan ke pendidikan yang lebih tinggi lagi, ikut bergabung dengan musyawarah guru atau perkumpulan guru IPS agar dapat saling bertukar informasi dan melakukan work shop bersama dalam rangka peningkatan mutu pendidik.

Selain menjadi fasilitator di kelas yakni memfasilitasi para siswa untuk mencari tahu dan memperoleh pengetahuan dari berbagai sumber baik buku maupun digital, peran guru pada era ini juga menjadi motivator bagi siswanya inilah yang menjadi 
penyemangat siswa-siswanya untuk terus semangat belajar dan berproses (Naufal, 2017).

Kemudian peran guru juga menjadi inovator untuk menemukan inovasi-inovasi baru dalam proses belajar mengajar agar nantinya para siswa tidak merasa bosan. Terakhir juga menghadapi peserta didik pada era industri 4.0 ini juga akan jauh berbeda dengan menghadapi siswa-siswa yang terdahulu. Untuk itu perlu sifat guru yang luwes, guru harus bisa menempatkan dirinya ada waktunya menjadi tegas dan ada waktunya menjadi sahabat dan orangtua bagi siswanya. Tidak ketinggalan juga adalah tentang pembaharuan kurikulum yang ada, percuma rasanya kalau segala sesuatu sudah di update dan upgrade namun kurikulum kita masih menggunakan kurikulum yang lama dan tidak relevan dengan perkembangan jaman, tentunya akan menjadi sia-sia. Perlunya sinergi yang baik antara pemerintah melalui kementrian pendidikan serta guru yang langsung menjadi ujung tombak dan mengerti kejadian langsung di lapangan. Pemerintah harusnya juga melihat kondisi dan kenyataan yang ada dilapang bukan hanya sekedar membuat kebijakan yang malah menjadi beban ganda bagi para guru.

Revolusi industri 4.0 ini diharapkan guru juga bisa mengeksplorasi kemampuan dan keterampilan yang dimiliki oleh siswa sehingga siswa mempunyai softskill yang bisa diandalkan setelah hard skill nya. Dunia pendidikan memberikan pengajaran keterampilan dan kemampuan khusus yang nantinya berguna bagi siswa di masa yang datang. Sebab itulah pendidikan dan pembelajaran Ilmu Pengetahuan Sosial diharuskan bertransformasi dan berevolusi agar sesuai dengan tuntutan dan perkembangan zaman, secara khusus adalah kemampuan menguasi keterampilan khusus yang harus dimiliki siswa. Keterampilan dalam pendidikan diungkapkan oleh (Sapriya, 2012) adapun keterampilan dalam dimensi pendidikan IPS meliputi: keterampilan dan kemampuan untuk meneliti, keterampilan dan kemampuan untuk bersosialisasi dan berpartisipasi sosial, terampil dan ahli dalam berpikir, terampil dan cakap dalam berkomunikasi”. Terdapat kompetensi yang harus dimiliki dalam era revolusi industri 4.0, yaitu: (1). Kompetensi pribadi, kompetensi seseorang dalam pengembangan kognitif dan sistem nilai, memiliki sikap kritis dan adaptif terhadap perkembangan teknologi. (2) Kompetensi sosial, kompetensi yang dibutuhkan meliputi: kemampuan komunikasi, koneksi sosial, bekerja sama, dan membangun struktur sosial dengan individu dan kelompok lainnya (Veerapaneni et al., 2020).

Akses segala sesuatunya yang begitu cepat dan kemudian ditandainya budaya luar yang bersebrangan dengan budaya bangsa. Sehingga akhir-akhir ini banyak anak muda Indonesia yang sudah tidak sejalan dan sama lagi dengan norma-norma yang ada di Indonesia. Untuk itu perlu yang namanya pendidikan, karena pendidikan adalah upaya dan cara untuk mentransmisikan nilai dan norma yang ada di masyrakat, nilai dan norma yang ada di masyarakat ini adalah sesuatu hal yang di anggap baik dan berharga serta benar. Pendidikan Ilmu pengetahuan Sosial harus bisa menjadi fasilitator dan pelopor dalam upaya membantu penanaman nilai, norma sosial yang ada di masyarakat, agar peserta didik mampu mengimplementasikan hal-hal yang diajarkan sebelumnya dalam kehidupan sehari-hari. 
Kemudian selanjutnya adalah dengan pendidikan karakter dan moral dapat membentengi siswa dari dampak negatif dunia luar. Karakter yang baik akan menjadi pondasi yang kuat dalam menghadapi revolusi industri 4.0. Tak lupa pula para pengajar Ilmu pengetahuan sosial menyisipkan nilai karakter dalam proses kegiatan pembelajaran IPS misalnya religius, kreatif, jujur, kerja keras, mandiri, toleransi, rasa ingin tahu, peduli sosial, tanggung jawab, cinta damai, dan sebagainya. Moralitas eksplisit berkaitan dengan proses sosialisasi personal. Tanpa moralitas manusia maka proses sosialisasi tidak dapat terlaksana. Moralitas merupakan nilai mutlak dalam seluruh kehidupan sosial. Penilaian etika didasarkan pada budaya masyarakat setempat. Moralitas adalah perilaku, sopan santun, atau kata-kata yang digunakan orang untuk berinteraksi. Jika tindakan seseorang sesuai dengan nilai-nilai indrawi yang berlaku di masyarakat itu dan dapat diterima dan disenangi oleh masyarakat tersebut, maka orang tersebut dianggap memiliki karakter moral yang baik, begitu pula sebaliknya. Moralitas adalah produk budaya dan agama. Setiap budaya memiliki standar moral yang berbeda berdasarkan sistem nilai universal yang telah lama terbentuk. Moralitas juga dapat diartikan sebagai sikap, perilaku, perilaku, dan perilaku seseorang ketika berusaha melakukan sesuatu berdasarkan pengalaman, penjelasan, hati nurani, dan nasihat.

Solusi yang efektif untuk pendidikan moral adalah dengan melaksanakan pendidikan karakter pada semua jenjang pendidikan mulai dari pendidikan dasar hingga pendidikan tinggi. Pendidikan karakter merupakan suatu sistem penanaman nilai-nilai karakter kepada anggota sekolah, termasuk konsumen pengetahuan, kesadaran, kemauan dan tindakan, sehingga dapat mengimplementasikan nilai-nilai tersebut kepada Tuhan Yang Maha Esa, diri sendiri, orang lain, lingkungan dan negara. Dengan penerapan pendidikan karakter maka karakter siswa akan terbentuk sejak sekolah dasar, kemudian dilanjutkan ke sekolah menengah pertama dan universitas. Dengan terbentuknya peran tersebut maka akan menjadi tameng atau pengontrol seseorang, sehingga akan mengontrol perilaku orang tersebut. Intinya jika karakter sudah terbentuk maka akan sulit untuk merubah karakter tersebut. Dengan menanamkan nilai-nilai yang baik dalam setiap proses pendidikan akan membantu proses pembentukan siswa yang berkarakter dan bermartabat.

Untuk itulah mengapa pembelajar Ilmu pengetahuan Sosial sangat penting dan menjadi salah satu sara pembentukan karakter. Bila semua yang sudah dipaparkan tadi berjalan dengan baik dan semestinya, besar kemungkinan kita bisa menciptakan pemuda dan pemudi atau anak-anak bangsa yang siap akan segala perkembangan jaman. Tentunya ini akan menjadi kelebihan kita dibalik semua hal-hal yang negatif dari revolusi industri 4.0 yang membawa banyak pengaruh didalamnya. Hal yang paling penting juga adalah sebuah kolaborasi antara semua pihak yakni antara orangtua, sekolah, masyarakat, pemerintah dan murid itu sendiri. Memang kelihatannya tidak mudah dan akan memakan banyak waktu, tapi hal seperti ini haruslah dilakukan secepat mungkin dan sedini mungkin agar penerus dan anak-anak bangsa kita bisa bersaing secara global dan tanpa harus meningggalkan nilai-nilai lokal yang mereka dan kita punyai. 


\section{Kesimpulan}

Sebuah tantangan akan mempunyai dampak yang baik apabila kita siap dalam menghadapinya. Era revolusi industri 4.0 ini harusnya bisa menjadi penyemangat kita untuk berubah kea rah yang lebih baik, karena didukung oleh banyak aspek-aspek kemudahan. Tapi akan menjadi bom waktu apa bila kita terlena dan tidak bisa ikut bersaing dengan global pada era revolusi industri 4.0. kita hanya bisa terlena dan menikmati tanpa disadari kita hanya sebgai kaum yang tertindas dan menjadi objek oleh kerasnya persainggan era revolusi industri 4.0. Segala akses dan segala sendi kehidupan yang berubah dan berganti begitu cepat mulai dari ekonomi, sosial dan budaya. Masyarakat perlu tahu dan bersiap menghadapi hal ini, jagan sampai ada gagar teknologi kemudian membuat gegar budaya yang merubah budaya Indonesia menjadi budaya dan kebiasan bukan asli Indonesia akibat mudahnya akses dan informasi yang didapat pada era ini.

Perubahan juga terjadi di dunia pendidikan, dunia pendidikan tak terelakkan juga ikut di jamah oleh revolusi industri 4.0. Penelitian dari McKinsey pada 2016 bahwa dampak dari digital tecnology menuju revolusi industri 4.0 dalam lima 5 tahun kedepan akan ada 52,6 juta jenis pekerjaan akan mengalami pergeseran atau hilang dari muka bumi. Penelitian ini menujukan adanya perlu penguatan ke siswa bukan hanya hardskill tapi juga pembekalan dan pembentukan softskill. Untuk itu perlu pendidikan IPS sebagai sarana karakter dan keperibadian. Pendidikan IPS dapat menjawab tantangan zaman dan diharapkan mampu untuk mentransformasi agar berguna untuk kehidupan siswa dalam menghadapi era revolusi industri 4.0. peran guru yang mampu menjadi fasilitator, motivator dan innovator. Guru juga harus terus ikut meng update dan upgrade pengetahuan serta cara pengajaran agar dapat mengimbangi para siswanya. Perubahan kurikulum yang juga harus bisa sejalan dengan perkembangan zaman. Paling penting dan utama adalah sinergi dari segala aspek mulai dari orang tua, sekolah, guru, masyarakat dan siswa itu sendiri untuk mau berubah dan proses agar bisa menghadapi tantangan perkembangan zaman. 


\section{BIBLIOGRAFI}

Adisusilo, Sutarjo. (2012). Pembelajaran Nilai-Karakter: Konstruktivisme dan VCT sebagai Inovasi Pendekatan Pembelajaran Afektif. Jakarta: PT Raja Grafindo Persada.

Akerib, D. S., Araújo, H. M., Bai, X., Bailey, A. J., Balajthy, J., Beltrame, P., Bernard, E. P., Bernstein, A., Biesiadzinski, T. P., \& Boulton, E. M. (2016). Improved limits on scattering of weakly interacting massive particles from reanalysis of 2013 LUX data. Physical Review Letters, 116(16), 161301.

Barr, Robert D., Barth, James L., \& Shermis, S. Samuel. (1977). Defining the social studies. National Council for the Social Studies Arlington, VA.

Darmiyati, Zuchdi. (2008). Humanisasi pendidikan. Jakarta: PT Bumi Aksara.

Ilbert, O., McCracken, H. J., Le Fèvre, O., Capak, P., Dunlop, J., Karim, A., Renzini, M. A., Caputi, K., Boissier, S., \& Arnouts, S. (2013). Mass assembly in quiescent and star-forming galaxies since $\mathrm{z} \simeq 4$ from UltraVISTA. Astronomy \& Astrophysics, 556, A55.

INDONESIA, PRESIDEN REPUBLIK. (2003). Undang-Undang Republik Indonesia Nomor 20 Tahun 2003 Tentang Sistem Pendidikan Nasional.

Irwan, S. K. M. (2017). Kearifan Lokal dalam Pencegahan HIV/AIDS pada Remaja.

Marhayani, Dina Anika. (2018). Pembentukan karakter melalui pembelajaran IPS. Edunomic: Jurnal Ilmiah Pendidikan Ekonomi Fakultas Keguruan Dan Ilmu Pendidikan, 5(2), 67-75.

Naufal, If'alul. (2017). Pengaruh penerapan pendekatan saintifik dan kreativitas guru terhadap motivasi belajar siswa kelas VIII pada mata pelajaran IPS di SMP Negeri 1 Candi Sidoarjo. Universitas Islam Negeri Maulana Malik Ibrahim.

Nursyifa, A. (2019). Transformasi pendidikan ilmu pengetahuan sosial dalam menghadapi era revolusi industri 4.0. Journal of Civics and Education Studies, 6(1), 51-64.

Sapriya, P. I. (2012). Konsep dan Pembelajaran. Bandung: Remaja Rosdakarya.

Sardiman, A. M. (2006). Pengembangan kurikulum pendidikan IPS di Indonesia: sebuah alternatif. Makalah, Disampaikan Pada Se $\neg$ Minar Internasional HISPISI Dengan Tema: Komparasi Pendi $\neg$ Dikan IPS Antar Bangsa, Di Semarang, 7-8.

Schwab, Klaus. (2017). The fourth industrial revolution. Currency.

Setiawan, I. Nyoman Anom Fajaraditya, Noorwatha, I. Kadek Dwi, Udayana, Anak Agung Gde Bagus, Wasista, I. Putu Udiyana, Jayanegara, I. Nyoman, Aditama, 
Gallih Arya Mulyadi dan Firman dan Rusdinal

Putu Wirayudi, Yasa, I. Wayan Adi Putra, Yasa, Ngakan Putu Darma, Anggara, I. Gede Adi Sudi, \& Setiawan, I. Ketut. (2020). Kapita Selekta Citraleka Desain 2020: Dialektika Seni, Desain, dan Kebudayaan Pada Era Revolusi Industri 4.0. STMIK STIKOM Indonesia.

Sumatri, Dinie. (2014). Pelatihan Rational Emotive Behaviour untuk Menurunkan Tingkat Communication Apprehension Mahasiswa.

Suwardana, Hendra. (2018). Revolusi Industri 4. 0 Berbasis Revolusi Mental. JATI UNIK: Jurnal Ilmiah Teknik Dan Manajemen Industri, 1(2), 109-118.

Veerapaneni, Rishi, Co-Reyes, John D., Chang, Michael, Janner, Michael, Finn, Chelsea, Wu, Jiajun, Tenenbaum, Joshua, \& Levine, Sergey. (2020). Entity abstraction in visual model-based reinforcement learning. Conference on Robot Learning, 1439-1456. PMLR.

Winataputra, U. S. (2010). Kebijakan Nasional Pembangunan Karakter Bangsa melalui Pendidikan Karakter(Konsep, Kebijakan, dan Kerangka Programatik. 